"closely lined from top to bottom with lepers, suffering from that loathsome disease in its worst forms and most advanced stages." A number of the victims examined by Mr. Boyle "presented a most sickening and awful spectacle." Yet no provision worthy of the name appears to be made for the maintenance or treatment of these poor lepers, who are thus coinpelled to resort to begging to keep themselves in existence. At Mandalay Mr. Boyle came in contact with horrors of a similar nature. During times of high festival the entrances of the great Arakan pagoda in that city are crowded by hundreds of lepers, so that the visitor has to pick his way carefully among them. In the Sandwich Islands also Mr. Boyle was strongly impressed by the terrible effects of the curse of leprosy, which, he says, has nearly decimated the native population.

He has a curious theory to the effect that the propagation of leprosy has been to a large extent connected with cannibalism, the disease "being spread wholesale through the eating of infected bodies." He has frequently seen in New Caledonia and the South Sea Islands human bodies "hanging up in the natives' huts, intended for future repasts, though then in an advanced stage of decomposition and exhaling a sickening odour."

The little book is by no means occupied only with these terrible subjects. Reference is made to many interesting things which came under Mr. Boyle's observation in the course of his journey. We may especially note the impression produced upon him by Buddhist temples and various classes of objects associated with Buddhism in Burmah. Pagan, an ancient capital of Burmah, situated on the Irrawaddy between Mandalay and Rangoon, contains an enormous number of Buddhist temples of various sizes and styles of architecture, and the city, as seen from the river, is described by Mr. Boyle as "one of the grandest and most impressive sights he has ever seen." Lower down the Irrawaddy below Prome there is a cliff about two miles long and 300 feet high, on the face of which are carved innumerable figures of Buddha ranged in tiers from the bottom to the top. He thinks that some of these figures cannot be less than twenty feet high. Many of them are richly gilded, and the whole forms "a very brilliant and curious sight." We reproduce an illustration showing the great recumbent figure of Buddha, in the province of Pegu, of which Mr. Boyle reports that "it is said to measure about 270 feet in length by 70 feet at the shoulder." In a paper read lately before the Anthropological Institute (see NATURE, November ro, p. 46) Major R. C. Temple gives the length as I8I feet and the height at the shoulder as 46 feet. This remarkable monument is built of brick, and Major Temple speaks of it as "well proportioned throughout." It is supposed to have been produced in the fifteenth century. It was hidden from view by jungle until I88I, when it was accidentally discovered by a railway contractor.

\section{GAUSS AND WEBER}

$\mathrm{I}^{\mathrm{N}}$ bringing before our readers the contents of a circular we have received with respect to the erection of a monument, in Göttingen, to the two world-renowned scientific workers and friends, Charles Frederick Gauss and William Weber, we do so, knowing that every scientific man, whether he be astronomer, mathematician, or physicist, will be only too glad to have a chance of paying some tribute, however slight, to their memory.

Only about a year has gone by since the younger of the two, William Weber, passed away, having brought glory to the University of Göttingen, which was radiated throughout the whole scientific world. The work which both have done in the service of science cannot be said to be the property of their followers alone, but is a precious heirloom of mankind, which has proved, and wlll continue to prove in the future, valuable in many ways in the service of technics, in methods of communication, and in civilization generally.

Gauss, who is almost unequalled among the scholars of the century, has not only left imposing landmarks of his great mind in all domains of pure mathematics, but he has also by his work furthered all departments of its applications in astronomy and physics, while his investigations have become standard for the theoretical as well as for the observational side

What Gauss did for magnetism, Weber, whom Gauss had chosen for his fellow-worker, attracted by his useful work on acnustics, did for the strength of galvanic currents, for their impelling electromotive forces, and for their resistances.

Further, in teaching how to measure these quantities in absolute units, he has furnished extremely important methods for their investigation. In this way not only has the science it:elf been furthered, but a firm basis for the development of electro-technics has been formed, the soundness of which is proved by its general adoption and which has contributed greatly to the tremendous advance witnessed during the last ten years. The pamphlet then goes on to say: "It is not the purpose of these lines to enlarge on the eminent works which we owe to the co-operation of these great investigators; we can only call to mind the fertile researches on the laws of the earth's magnetism, from which as it were a new branch of physics has developed; further, the attempts to encompass the phenomena of electrostatics, electrodynamics, and induction by one single law, attempts which, however a future generation may judge of them, will mark an important epoch in scientific development; and further, we may recall the most popular result of their co-operation, viz. the erection of the first telegraph practically adopted for communication at a distance."

Since the year 1877 the birthplace of Gauss has possessed a memorial of him, but Göttingen, the place where he and Weber worked, and where the former died, and which consequently became celebrated, possesses no such memorial. That this should be remedied is the object of this circular, and one has only to glance down the list of names attached to it-about 275 altogetherto see that it inciudes most of the learned men in Germany, and those of many distinguished foreigners. Among these we are glad to see the name of Lord Kelvin, President of the Royal Society.

The acting committee is composed of Prof. Klein, E. v. Meier (Curator of the University), F. Merkel (Prorector of the University), G. Merkel (Over-burgomaster), Profs. E. Riecke, E. Schering, W. Schur, W. Voigt, H. Weber, and S. Benfey (banker), and it is to the last mentioned that subscriptions should be addressed ( $\mathrm{S}$. Benfey, Bankgeschäft, Göttingen). The list will remain open until April I, I893.

\section{THE ANNIVERSARY OF THE ROYAL • SOCIETY.}

Y ESTERDAY being St. Andrew's Day the anniversary meeting of the Royal Society was held in their apartments at Burlington House. The auditors of the Treasurer's accounts having read their report, and the Secretary having read the list of Fellows elected and deceased since the last anniversary, the President (Lord Kelvin) proceeded to deliver the anniversary address. The medals were then presented as follows :-The Copley Medal to Prof. Rudolf Virchow, For.Mem.R.S. (received by the Foreign Secretary), for his investigations in Pathology, Pathological Anatomy, and Prehis-

NO. I 205 , vOL. 47$]$ 